\title{
Impact of Farmscaping on Abundance of Campoletis chlorideae (Uchida) on Gram Pod Borer
}

\author{
G. Chhangani*, A. Vyas and M. K. Mahla \\ Department of Entomology, Rajasthan College of Agriculture (MPUAT) Udaipur, India \\ *Corresponding author
}

\section{A B S T R A C T}

\begin{tabular}{|l|}
\hline K e y w o r d s \\
Gram, gram pod borer, \\
farmscaping, larval \\
parasitoid, Campoletis \\
chlorideae
\end{tabular}

\section{Introduction}

Chickpea (Cicer arietinum L.) is among the most widely consumed legumes in the world, particularly in tropical and subtropical areas. Bengal gram, gram or chana is an important rabi pulse crop of India and has been considered as 'King of Pulses' (Bhatt and Patel, 2001). In India the major insect pest of chickpea is the gram pod borer, Helicoverpa armigera (Hubner) (Lepidoptera: Noctuidae) which is polyphagous, multivoltine and is cosmopolitan pest. It is known to feed on 182 species of plants belonging to 47 families in India (Sithanantham, 1987 and Panwar, 1998) and on more than 250 crop species (Kranthi et al., 2002 and Jiirgen et al., 1977). The gram pod borer, H. armigera (Hubner) is known to cause about 29 per cent yield losses in chickpea at national level. High polyphagy, mobility, reproduction rate, and diapause are major factors contributing to its serious pest status (Fitt, 1989). The gram pod borer begins infestation at the seedling stage and later feeds on the flower and developing seeds in pods until crop maturity (Mandal and Roy, 2012). Over 250 natural enemies have been recorded on $H$. armigera (Romeis and Shanower, 1996), of which, the egg parasitoids, Trichogramma spp. and the larval parasitoids, Campoletis chlorideae Uchida (Hymenoptera: Ichneumonidae), Carcelia illota Curran, Palexotista spp., and Goniozus spp. are predominant parasitoids of $H$. armigera in different agro-ecosystems. However, the activity and abundance of natural enemies 
varies across crops (Pawar et al., 1986) Farmscaping is a holistic approach to manage insect pests on farms that focus on increasing biodiversity in order to maintain healthy populations of beneficial insects, birds and other wildlife as part of an ecological pest management program

\section{Materials and Methods}

The present investigation was conducted at Instructional Farm of Rajasthan College of Agriculture, Udaipur, during 2017-18. Sowing of gram variety GNG-1581 with different farmscaped plants viz., mustard, marigold and sunflower was done (table-1). This experiment was laid down in a RBD with three replications. The associated natural enemies Observations were taken by collecting second instar or early third instar larvae of pod borer from the tagged rows at 40 DAS and 60 DAS interval. The field collected larvae were maintained in glass jars covered with muslin cloth held by rubber bands in laboratory. The larvae were reared on fresh leaves and pods of gram until pupation or emergence of the parasitoid. The effective parasitization (\%) was computed using the methodology adopted by Hugar et al., (2014) and Tian et al., (2008).

No. of parasitoids emerged

Parasitization $(\%)=$--------------------- X 100

No. of larvae collected

Foliar applications of NSKE (5\%) as prophylactic spray after one month of germination and Ha NPV @ 250 LE/ ha (when 1-2 larvae per m-row was observed) were given in the treated plots.

\section{Results and Discussion}

The maximum parasitization was observed in the gram farmscaped with marigold followed by that in gram bordered with mustard and then in gram bordered with sunflower. Gram without farmscape had minimum per cent parasitization. Out of 95 fields collected larvae reared in laboratory 45 larvae were parasitized which worked out to be 43.15 per cent parasitisation.

From tables (2-3) it can be observed that farmscaping treatments were best along with bioprotectant. The per cent parasitisation was maximum in farmscaped treatments. It was found that at 40 DAS gram bordered with marigold with bioprotectant had maximum $(75.00 \%)$ parasitisation; whereas it was minimum $(25.00 \%)$ in gram without farmscape treatment.

Similarly, 60 DAS the maximum parasitisation $(66.66 \%)$ was recorded in gram bordered with marigold and minimum (40.00 $\%)$ parasitisation in gram without farmscape treatment.

Similar to our findings, Bisane et al., (2009) showed that among early instar larvae, 34.55 per cent mortality was noticed, in which highest parasitization (14.89 per cent) was due to Eriborus argenteopilosus Cameron and 8.94 per cent due to $C$. chlorideae Uchida. According to Pandey (2009) parasitization by C. chlorideae did not vary among the intercrops during pre-winter months of rabi 2004-05; however parasitization was higher in chick pea + linseed $(4: 2)$.

Studies by Pandey et al., (2012) revealed that mean larval parasitization ranged from a maximum of 30.16 per cent in chickpea + coriander (4:1) to minimum of 15.73 per cent in chickpea + barley $(6: 1)$ as compared with 15.98 per cent in chickpea sole crop. Similarly, Agnihotri et al., (2011) observed $C$. chloridae, a larval parasitoid of $H$. armigera (Hubner), in chickpea crop during $3^{\text {rd }}$ SMW of the year in both the cropping seasons with parasitization of up to 78.57 and 80.00 per cent, respectively. 
Table.1 different farmscaping treatments

\begin{tabular}{|c|l|}
\hline \multicolumn{1}{|c|}{ Treatment } & \multicolumn{1}{c|}{ Details } \\
\hline$T_{1}$ & Gram without farmscaping (Untreated) \\
\hline$T_{2}$ & Gram without farmscaping(Treated) \\
\hline$T_{3}$ & Gram bordered with Mustard (Untreated) \\
\hline$T_{4}$ & Gram bordered with Mustard (Treated) \\
\hline$T_{5}$ & Gram bordered with Marigold (Untreated) \\
\hline$T_{6}$ & Gram bordered with Marigold (Treated) \\
\hline$T_{7}$ & Gram bordered with Sunflower (Untreated) \\
\hline$T_{8}$ & Gram bordered with Sunflower (Treated) \\
\hline
\end{tabular}

Table.2 Parasitization of $H$. armigera by the larval parasitoid $C$. chlorideae under different farmscape treatments at 40DAS during rabi, 2017-18

\begin{tabular}{|l|c|c|}
\hline \multicolumn{1}{|c|}{ Framscape treatments in gram } & \multicolumn{2}{|c|}{ Parasitization (\%) 40 DAS } \\
\cline { 2 - 3 } & Treated & Untreated \\
\hline Without any farmscaping & 25.00 & 33.33 \\
\hline Bordered with mustard as farmscape & 33.33 & 50.00 \\
\hline Bordered with marigold as farmscape & 50.00 & 75.00 \\
\hline Bordered with sunflower as farmscape & 25.00 & 33.33 \\
\hline
\end{tabular}

Table.3 Parasitization of $H$. armigera by the larval parasitoid $C$. chlorideae under different farmscape treatments at 60DAS during rabi, 2017-18

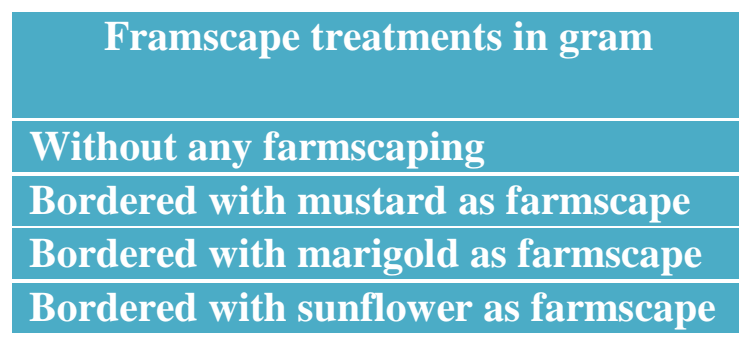

\section{Acknowledgement}

The senior author is thankful to the Dean, Rajasthan College of Agriculture and Head, Department of Entomology, Udaipur for providing necessary facilities for the present investigation.

\section{References}

Agnihotri, M., Gairola, S. C. and Basera, 2011. Seasonal incidence of $C$.

\begin{tabular}{|c|c|}
\hline \multicolumn{2}{|c|}{ Parasitivation (\%) 60 DAS } \\
\hline Treated & Untreated \\
\hline 40.00 & 42.00 \\
\hline 64.00 & 66.66 \\
\hline 69.00 & 75.00 \\
\hline 57.00 & 60.00 \\
\hline
\end{tabular}

chloridae, a larval parasitoid of $H$. armigera (Hubner) in chickpea. J. Ins. Sci. (Ludhiana) 24:362-366.

Bisane, K. D., Nehare, S. K. and Khande, D. M., 2009. Extent of parasitization of $H$. armigera by larval and papal parasitoids on chickpea. J. Ento. Res., 32: 295-301.

Fitt, G. P., 1989. The ecology of Heliothis in relation to agroecosystems. Ann. Re. Ento., 34: 17-52.

Hugar, S. V., Sharma, H. C., and Goud, K. B., 2014. Pigeonpea genotype influence 
parasitization preference and survival and development of $H$. armigera larval parasitoid C. chlorideae. Springer Plus, 3: 378

Jiirgen, K., Heinj, S. and Warner, K., 1977. Pests in tropical crop. In: disease, pest and weed in tropical crops. John Willy and Sons, New York, Brisbane. Toronto. Pp 479-481.

Kranthi, K. R., Jadhav, D. R., Kranthi, S., Wanjari, R. R., Ali, S. S. and Russel, D. A., 2002. Insecticide resistance in five major insect pests of cotton in India. Crop Prot., 21: 449-460

Mandal, S. K., and Roy, 2012. Impact of environmental factor (s) on certain pulse crops of north-eastern Bihar (India) with reference to resource management. The Ecoscan, 1: 35-40.

Pandey, B. M., Tripathi, M. K., and Lakshmi, V., 2012. Seasonal incidence of gram pod borer $H$. armigera (Hub.) on chickpea in Varanasi area. J. Experi. Zoo, 15: 667-669.

Pandey, R., Ujagir, R., 2009. Effect of intercropping on $C$. chloridae, a larval parasitoid of $H$. armigera in chickpea. J. Ins. Sci., 22: 227-231.
Pawar, C. S., Bhatnagar, V. S. and Jadhav, D. R., 1986. Heliothis species and their natural enemies, with their potential for biological control. Proceedings of the Indian Academy Sciences (Animal Sciences), 95: 695-703.

Pawar, V. M., 1998. Microbial control of $H$. armigera on pulse crops. In: IPM system in Agriculture (Upadhyaya R. K., Mukherjii K. G., Rajak R. L., Eds) New Delhi, India, Aditrya Books Private Ltd. 55-78.

Sithanantham, 1987. Insect pests of chickpea and pigeon pea and their management. In: plant protection in Field crops (Veerabhadra R. M. and Sithanantham s., Eds) Hyderabad, A.P., India: Plant Protection Association of India, 159173.

Tian, S. P., Zhang, J. H., Yun- Hua, Yan, Y. H., and Wang, C. Z., 2008. Interspecific competition between the ichneumonid $C$. chlorideae and the braconid Microplitis mediator in their host $\mathrm{H}$. armigera. Ento. Experi. App. 127: 1019.

\section{How to cite this article:}

Chhangani G., A. Vyas and Mahla M. K. 2018. Impact of Farmscaping on Abundance of Campoletis chlorideae (Uchida) on Gram Pod Borer. Int.J.Curr.Microbiol.App.Sci. 7(06): 3217-3220. doi: https://doi.org/10.20546/ijcmas.2018.706.378 